\title{
The Mesolithic inhumation at Brunstad - a two-step multidisciplinary excavation method enables rare insights into hunter-gatherer mortuary practice in Norway
}

\author{
Almut Schülke ${ }^{1}$, Kristin Eriksen ${ }^{2}$, Sara Gummesson $^{3}$, Gaute Reitan ${ }^{1}$ \\ ${ }^{1}$ Museum of Cultural History, University of Oslo, Postboks 6762, St. Olavs plass, 0130 Oslo, \\ Norway \\ ${ }^{2}$ Arkeologerna, Statens historiska museer, Instrumentvägen 19, 12653 Hägersten, Sweden \\ ${ }^{3}$ Osteoarchaeological Research Laboratory, Stockholm University, Sweden
}

Abstract

The Mesolithic burial from Brunstad, Vestfold, Eastern Norway, dating to c. 5900 cal BC, represents rare evidence of Mesolithic mortuary practice in Norway. While Mesolithic settlement finds are abundant in the region, evidence of mortuary ritual is virtually absent in the record. In this article we present the method and the results of the multidisciplinary excavation, on-site and in the laboratory. The challenging Brunstad find was excavated in two steps, and later reconstructed, involving osteology, 3D photogrammetry and conservation. Moreover, the burial is discussed in its local, regional and supra-regional context. While the inhumation of an adult individual in a flexed body position is rare in its regional context, it exhibits typical features known from Mesolithic graves in Scandinavia as well as from other parts of Europe. These include the shore-based island location and proximity to a settlement site, the body position, as well as certain features of mortuary ritual. In the light of Mesolithic mortuary practices in Scandinavia and the Baltic region, from where many Mesolithic graves are known, we suggest that Mesolithic hunter-gatherers in Eastern Norway and the Skagerrak region handled and disposed of their dead in various ways, some of which might not have left archaeological traces. We conclude that the Brunstad grave represents a distinct mode of burial at the time. 


\section{Highlights}

- Rare inhumation sheds light on Mesolithic mortuary practice in Norway

- Interdisciplinary two-step excavation allows reconstruction of flexed body position

- Burial exhibits traits of hunter-gatherer graves across Europe

- Site context gives insight into hunter-gatherer ritual and mobility

- A distinct burial at its time

\section{Keywords}

Inhumation, Mesolithic, Norway, osteology, 3D photogrammetry, flexed body position, mortuary practice

\section{Introduction and background}

In contrast to Southern Scandinavia and other parts of the Baltic Sea region, from where a number of Mesolithic open-air single burials and grave fields are known, such mortuary evidence is, generally speaking, lacking in Middle and Northern Scandinavia. Poor preservation conditions for osseous material in the acid soils of the coniferous zone are regarded as the main reason for the missing evidence. The few known finds of Mesolithic human remains from Norway originate almost exclusively from locations with more favourable preservation conditions, such as wetlands, submerged sites and caves (Bergsvik and Storvik, 2012; Skar et al., 2016). Within this regional context, the recent find of an inhumation, dating to $c .5900 \mathrm{cal}$ BC, at a Mesolithic coastal site at Brunstad, Vestfold, in Eastern Norway, is exceptional. In a supra-regional perspective, however, the grave exhibits traits of mortuary practices known from Mesolithic burials in other parts of Europe, with regard to location, grave structure and the body position of the deceased. The excavation of the Brunstad grave was challenging, due to several factors, such as poorly preserved bones and very hard surrounding sediments. In this article, we present the results that were gained by choosing a multidisciplinary excavation method in two steps - on-site and in the laboratory - including conservation, osteology and 3D photogrammetry. Furthermore, the burial is discussed in its local, regional and supra-regional context. 


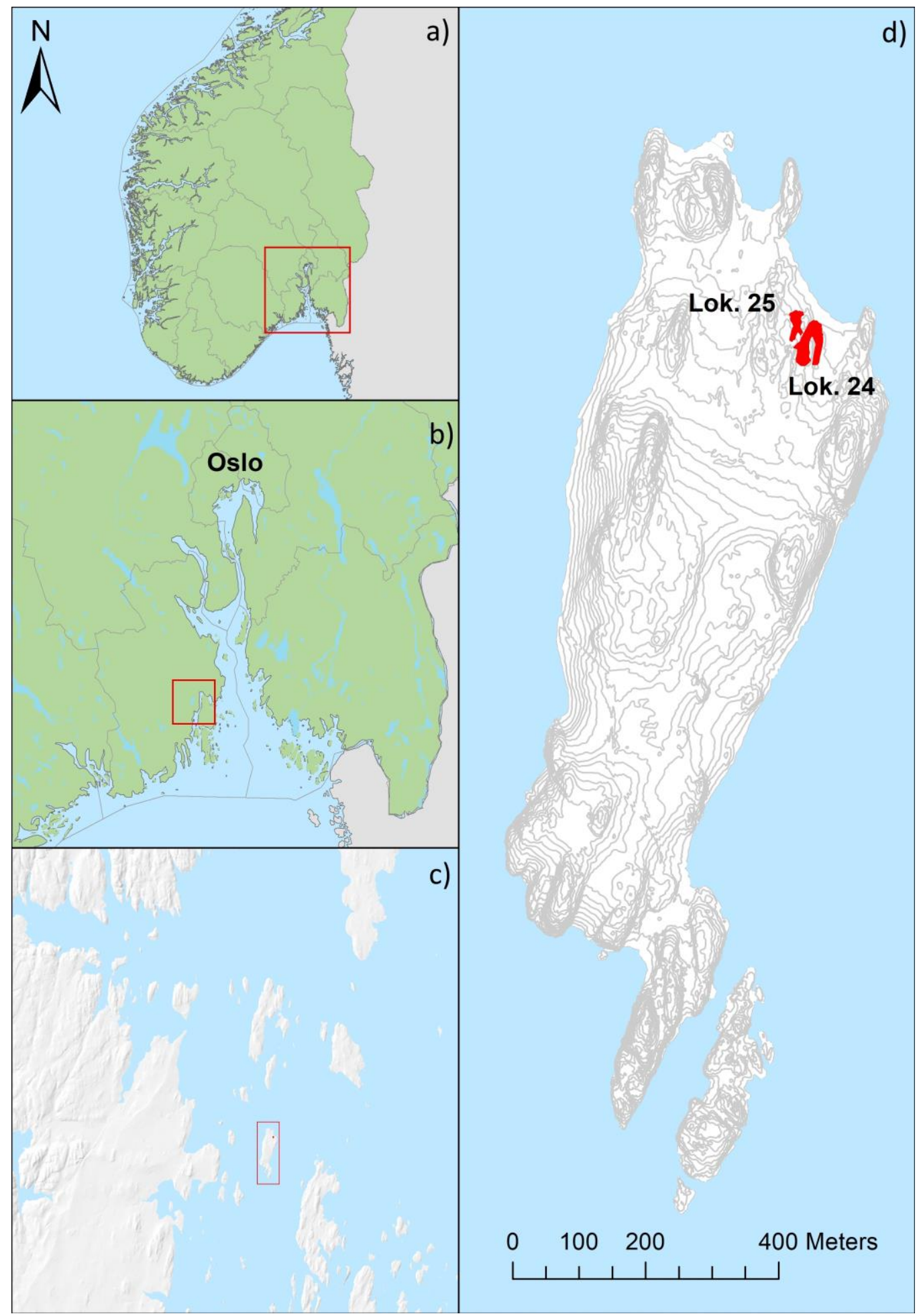

Fig. 1: Today's location of the Brunstad sites lok. 24 and lok. $25(a), b)$ ). In the centuries around $5900 \mathrm{cal}$ BC they were placed on an island, according to the sea-level of $49 \mathrm{~m}$ a.s.l. at the time (c) and d)) (cf. Henningsmoen 1979; Persson 2008) (Map: Kristin Eriksen, MCH, $\mathrm{UiO})$. 
The grave at Brunstad was discovered in 2014 during a development-led excavation conducted by the Museum of Cultural History (MCH), University of Oslo (Fig. 1). Two adjacent Mesolithic sites, lok. 24 and lok. 25, were investigated (Fig. 2). The sites were separated only by an elongated rocky outcrop. Technological traits of the predominant lithic artefacts (nearly 16,000 objects), and radiocarbon dates from eleven of the more than 40 structures that were found, substantiate that the sites were visited repeatedly in the period $c$. 6400-5700 BC. This corresponds to the first part of the Late Mesolithic Nøstvet phase, according to the established chronology for the region (Glørstad, 2010; Jaksland, 2001; Mikkelsen, 1975; but cf. Reitan, 2016). The two sites were situated at 50-54 m above today's sea level and $700 \mathrm{~m}$ away from the present shoreline. At their time of use, however, they were shore-based and located on a small island in the inner archipelago on the west side of the Oslo Fjord (Fig. 1). The grave was found at lok. 25 between two rocky outcrops (Fig. 2). Despite an intensive search, no other evidence of burial structures was recorded from either of the two sites.

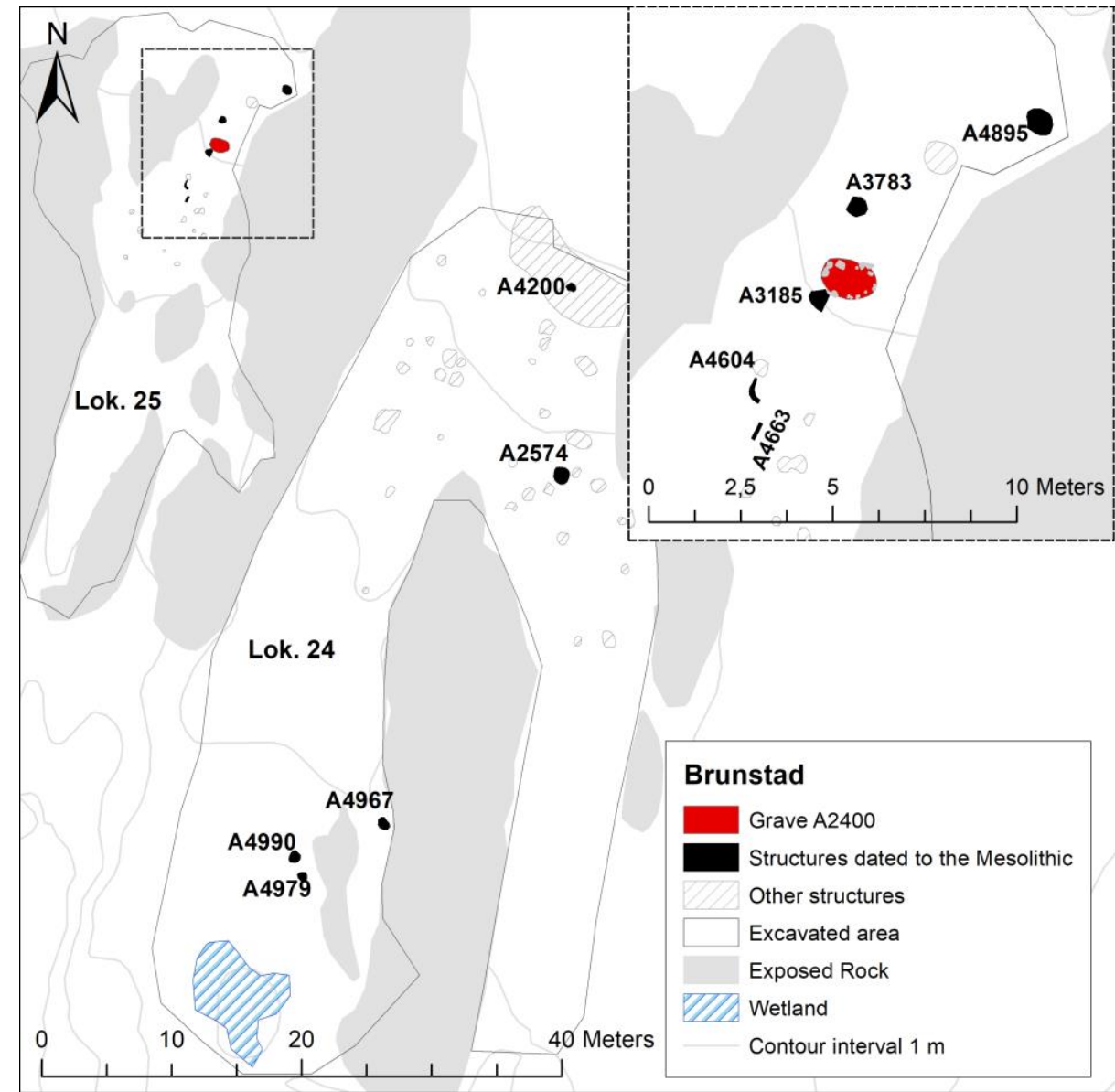

Fig 2: The adjacent Brunstad sites (lok. 24 and 25) with the Mesolithic grave at lok. 25. The ten other structures (nine hearths and a cultural layer) that are radiocarbon-dated to the 
Mesolithic (compare Table 1 and Fig. 10) are highlighted in black (Map: Kristin Eriksen, $\mathrm{MCH}, \mathrm{UiO})$.

In contrast to the general lack of mortuary evidence, hundreds of Late Mesolithic settlement sites are known from Eastern Norway. Most of them were coastal sites at the time of occupation, typically located in positions similar to the Brunstad sites: sheltered, between rock outcrops, and sometimes on relatively thick sandy soils in an otherwise rocky coastal region with thin soil cover (Glørstad, 2010). These settlement sites have, besides lithic artefacts, also yielded structures such as hearths and in some cases remains of huts (e.g. Glørstad, 2010; Fretheim, 2017). There is, however, poor preservation for bone, and despite targeted investigations, no Mesolithic burials have been found (Glørstad, 2004). The geographically closest burial evidence from this period is the double grave from Uleberg, Bohuslän, on the other side of the Skagerrak strait in Western Sweden, at roughly 100 kilometres linear distance from Brunstad, with two individuals in flexed positions in a stone cist, dated to c. 5600 cal BC (Niklasson, 1932; Nordqvist, 2000; Sjögren and Ahlström, 2016, no. 7) (cf. Fig. 11). Thus Uleberg and Brunstad are the only inhumations so far known from the Nøstvet phase in Eastern Norway and Western Sweden (cf. Glørstad, 2010).

Consequently, the question of whether Brunstad has to be regarded as a fortuitously wellpreserved specimen of usual Late Mesolithic burial practice in the area (Glørstad, 2010: 243), or whether this type of burial was special within the region during this period, must be discussed in a wider perspective. In this article we suggest, in the light of a broader discussion of Mesolithic mortuary practices in Scandinavia and the Baltic region, that Mesolithic huntergatherers in Eastern Norway and the Skagerrak region handled and disposed of their dead in different ways, with the Brunstad grave representing a distinct mode of burial at the time.

\section{Material and Method}

The grave (structure $A 2400$ at lok. 25; see Fig. 2) was found immediately under a baulk profile which was laid out to cut lok. 25 lengthways (Fig. 3). After the removal of the topsoil a dark colouring was visible. It was first interpreted as a larger pit that was narrowing towards the bottom and excavated in $25 \times 25 \mathrm{~cm}$ squares and in layers of $10 \mathrm{~cm}$ thickness. Once human remains (cranial fragments) were identified centrally in the pit at approximately $50 \mathrm{~cm}$ depth, the excavation method was changed and the structure was treated as a possible grave. 


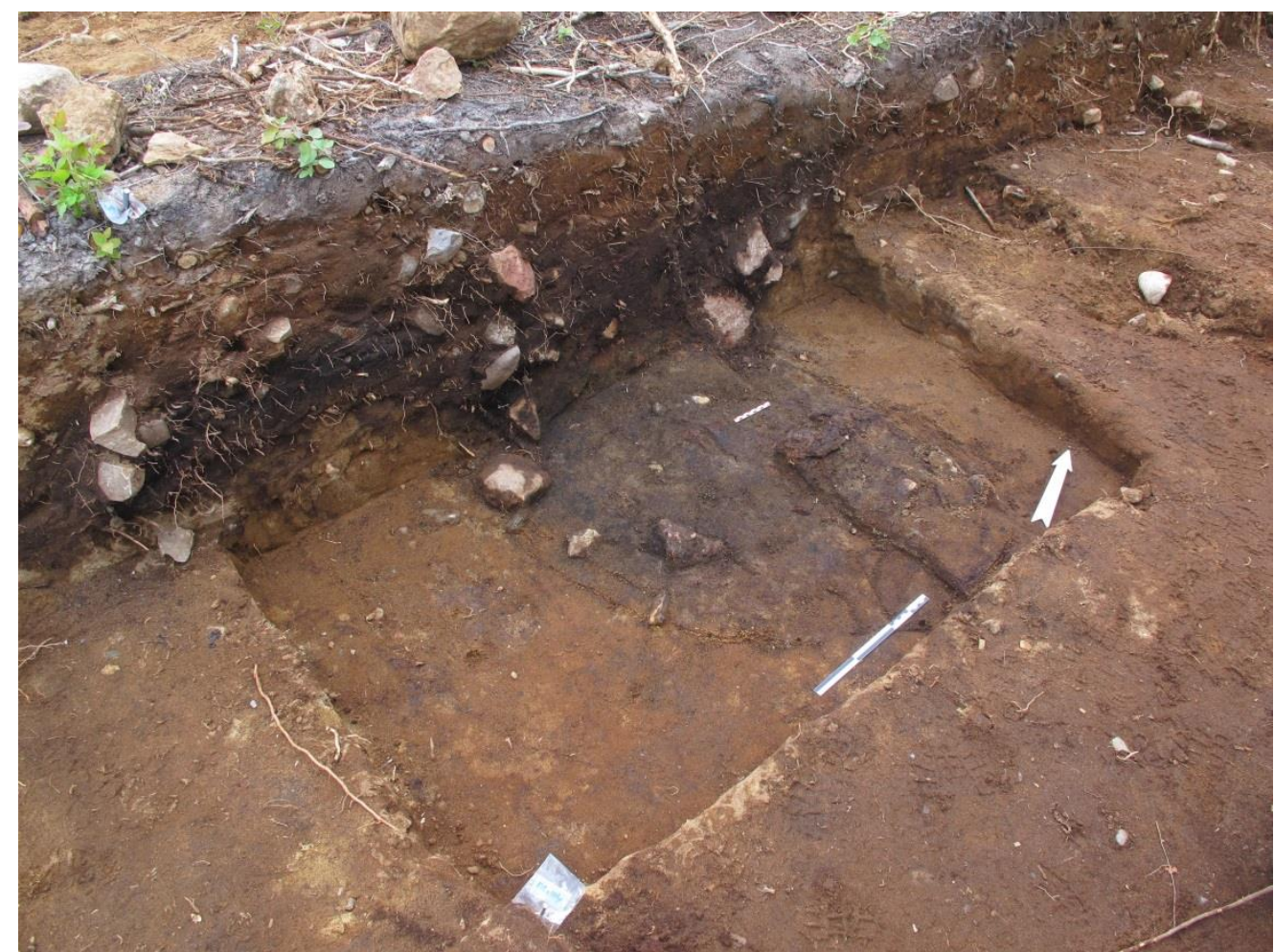

Fig. 3: The grave pit, half of it visible in planum, was cut transversely by a baulk profile, $c f$. Fig. 6 (Photo: Gaute Reitan, MCH, UiO).

The profile baulk was documented (Fig. 6) and removed, and the structure was exposed in planum.

The human bones were poorly preserved, while at the same time the enclosing soil was so hard that an excavation on site could have destroyed important evidence. To safeguard the scientific potential of the find, a multidisciplinary approach with a two-step excavation - onsite and later in the laboratory - was chosen, combining archaeology, conservation, osteology and GIS methods. A first attempt to recover the burial en bloc had to be abandoned, because most of the remains of the deceased were found on the bedrock at the bottom of the pit. Instead the find, encompassing the hard soil of the grave context which included the bones, was extracted in smaller blocks. With the expert help of two conservators the smaller blocks were cut in such a way that the remains were not uncontrolledly damaged while at the same time their sediments were also preserved (Fig. 4). Thus the find was gradually sectioned into 10 blocks and a number of small fragments (Fig. 5, Supplementary material 1). 


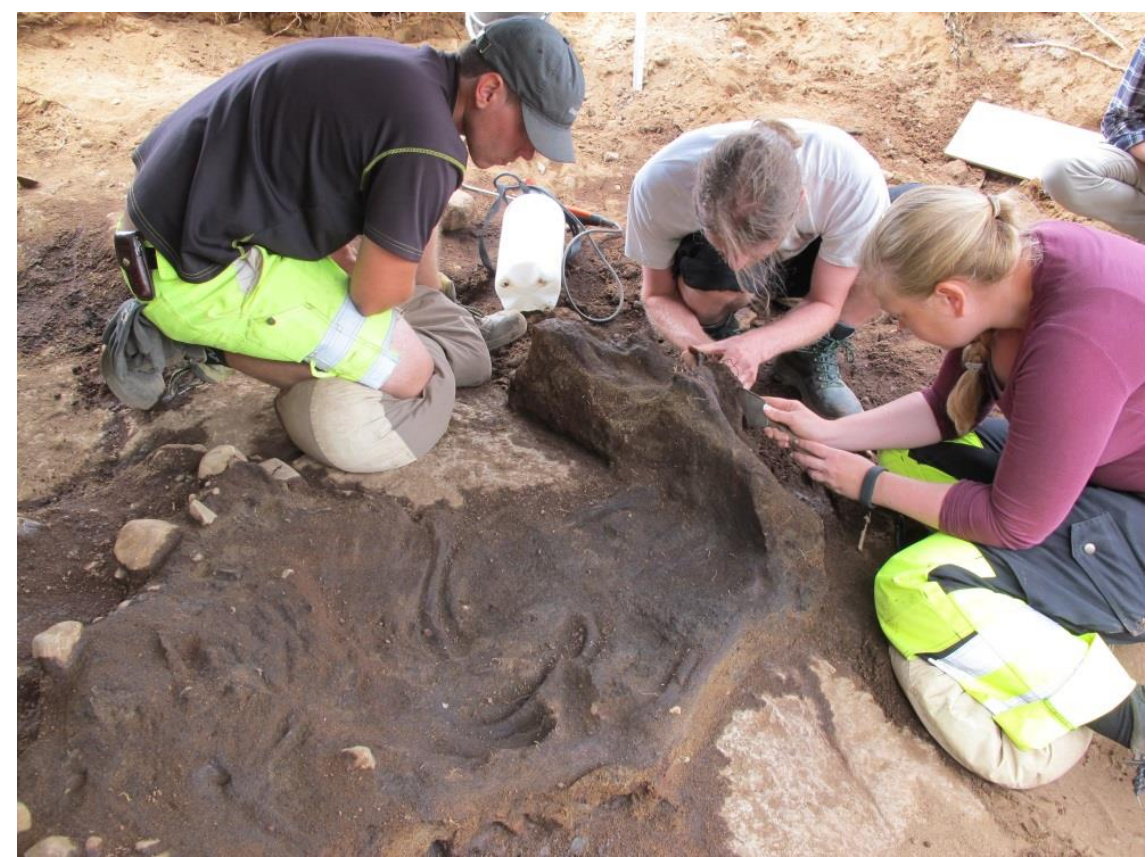

Fig. 4: The burial was extracted in smaller blocks. Visible on the picture (taken towards southwest) are the bones of the right arm, ribs and the flexed legs, cf. Fig. 7 (Photo: Gaute Reitan, $M C H, U i O)$.

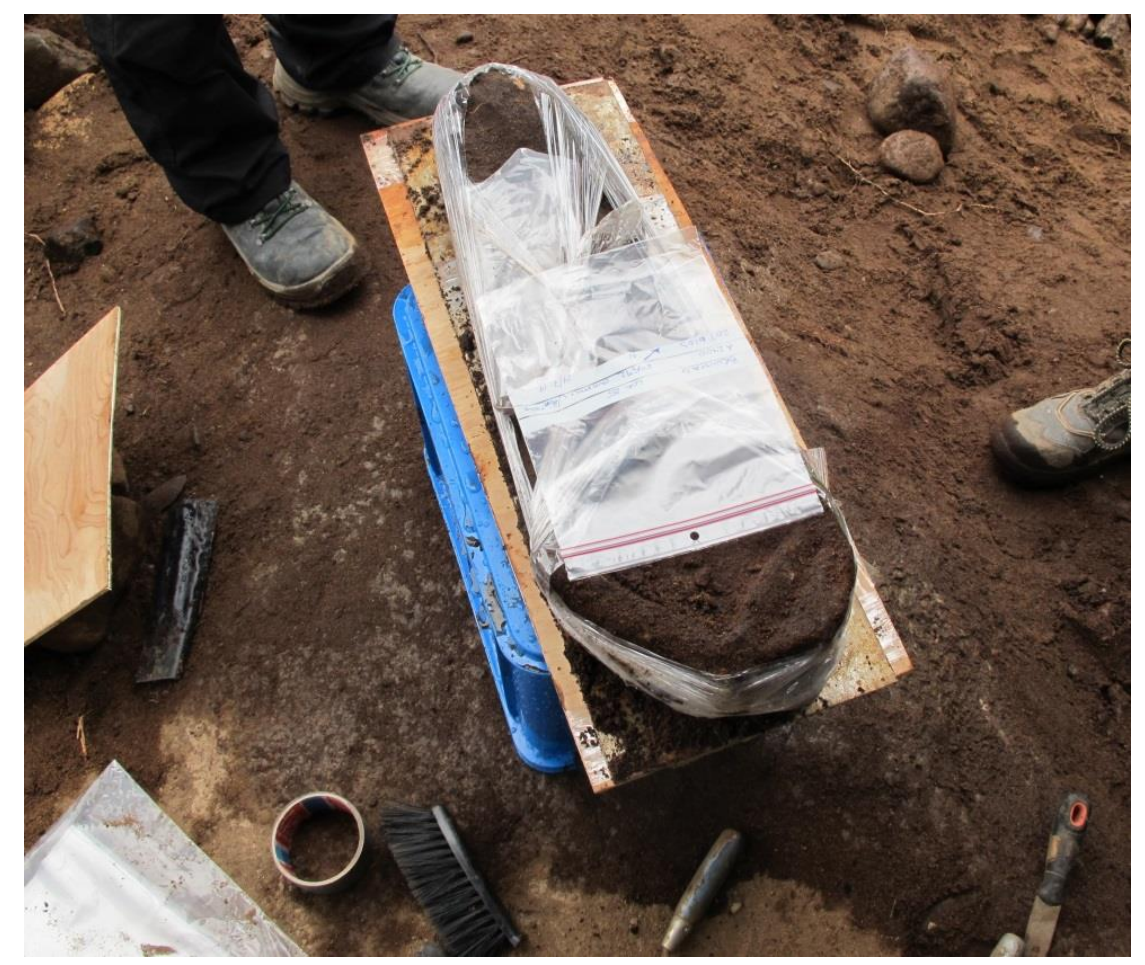

Fig. 5: The blocks were cut and wrapped in the field (Photo: Gaute Reitan, MCH, UiO).

This strategy required a documentation method which could ensure the later reconstruction of the burial. To reach this goal, a thorough GIS documentation was conducted. 3D 
photogrammetry was applied, both in the field and later in the lab. The method used was Structure from Motion (SfM), which extracts three-dimensional data from photographs to create a 3D scene (Green et al., 2014). This involves taking photographs of the object of interest from all sides. The photographs need to have enough overlap to be processed with computer software to create a point cloud and a mesh. The software used was Agisoft Photoscan. The aim of this procedure was to document the grave context, the position of the bones, and any grave goods. In the field, the grave was documented and photographed (camera: Canon PowerShot G16) at three levels: 1) before removing the stone accumulation; 2) after removing the first level of blocks; and 3) after removing the block, which contained the bones of the legs (see below). The blocks (Supplementary material 1) were measured before removal and provided with id numbers and ground control points (GCPs) as reference points for the $3 \mathrm{D}$ model.

Subsequently, the blocks were excavated in a controlled environment at the conservation laboratory of the $\mathrm{MCH}$. Excavation was conducted by an osteologist, while a conservator secured measures to preserve the bones. During this process, each of the blocks was given new GCPs. A series of photographs was taken before excavating each block; during the excavation new series were taken continuously at different levels.

The bones excavated from the blocks, their spatial position and interrelation were digitally plotted in 3D models and combined with the models made on the basis of the documentation in the field (software: Agisoft Photoscan). Together they provide a reconstruction of the remains of the burial (see Fig. 7, 8 and 9). Features that appear to be bone which in reality had too little osseous material left to be recovered can also be seen. These traces of the skeleton are visible as faint imprints in the model.

\section{Results}

\subsection{The grave}

The grave was east-west oriented and placed between two rocky outcrops on a soft slope which dropped down towards the prehistoric shoreline (Fig. 2). The grave pit was identifiable from about 20-25 cm depth as a dark fill in the surrounding sandy soils (Fig. 6, layer 5). Its shape was oval to rectangular, measuring approximately $150 \times 110 \mathrm{~cm}$ (Fig. 3). Measured from the turf it was 80-90 cm deep (Fig. 6). In the west, it was dug down to the bedrock, and in the east it was cut into a natural layer of gravel. The bottom of the grave pit was carefully lined with stones along the sides (Fig. 7). The position of the bones shows that the deceased 
was placed on the bottom of the pit (see section 3.2). The bones were covered by a layer of fine sand with small inclusions of gravel and charcoal (Fig. 6, layer 7).

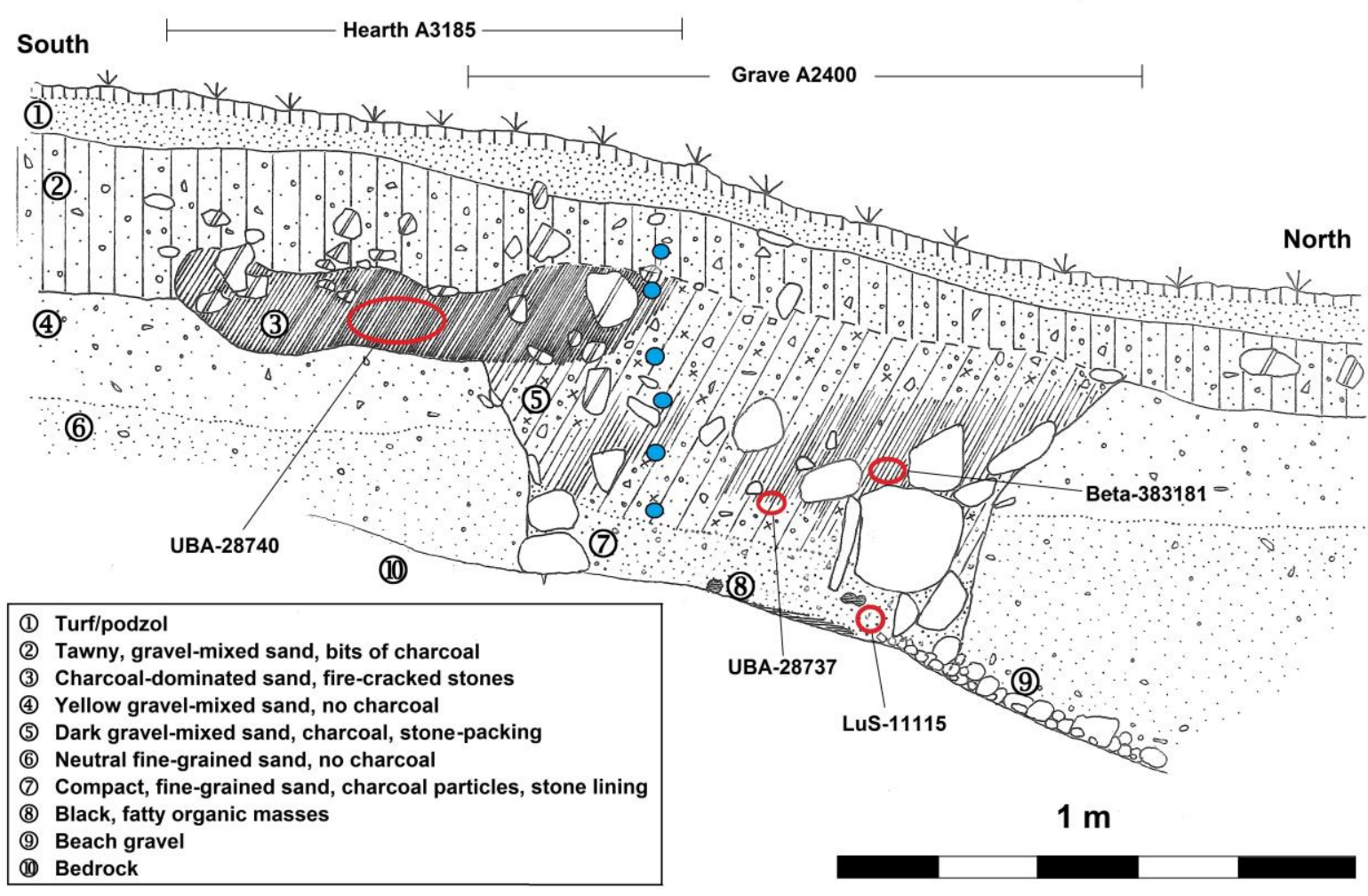

Fig. 6: Cross-section (south-north) of the grave pit, with intersecting hearth A3185. Heights for ${ }^{14} \mathrm{C}$ samples (red) and pollen samples (blue, samples 1-6 counted from bottom to top) are marked (Drawing: Gaute Reitan, $\mathrm{MCH}, \mathrm{UiO}$ ).

Superimposed on this layer of fine sand, and $40-50 \mathrm{~cm}$ below the turf, was a layer of loosely packed unburned stones (Fig. 6, layer 5), which stood in clear contrast to the lower density of the stones at lok. 25 in general. The stones had a diameter of between roughly 15 and $35 \mathrm{~cm}$. The fill in this upper level of the grave pit consisted of homogeneous, dark, charcoal-mixed sand and gravel (Fig. 6, layer 5). The grave contained stones with a total weight of more than $350 \mathrm{~kg}$, including the lining along the sides of the pit.

No traces of ochre, often recognized in Mesolithic burials (e. g. Brinch Petersen, 2016: 101105), were observed.

About 100 lithic finds, $90 \%$ of which are of flint, were found at different levels in the grave fill. Amongst these were a few fragments of tools, for example a sandstone knife, a flint burin and a flint scraper. These finds resemble typical settlement debris, and were most likely part 
of the backfilled masses. One flint flake found close to the right upper arm of the skeleton could possibly represent an intentional deposition. However, the interpretation of such an object as grave goods is problematic (e.g. Kjällkvist, 2001; Larsson, 2016).

\subsection{Osteological analysis}

The skeletal material from the grave was generally poorly preserved. The majority of the bone elements were only visible as dark soil colourings (compare Fig. 7 and 8, see also Fig. 4). The preserved bones (see Supplementary material 2) were also damaged by several smaller roots, growing both in the medullar cavity and in the cortex of the bones. Only human bones were identified and no overlapping elements were recovered, which indicates that the burial only contained one individual. Cranial fragments, including the remains of the mandibula, elements from both the upper and lower extremities and the right and left side of the skeleton were represented (Fig. 7).

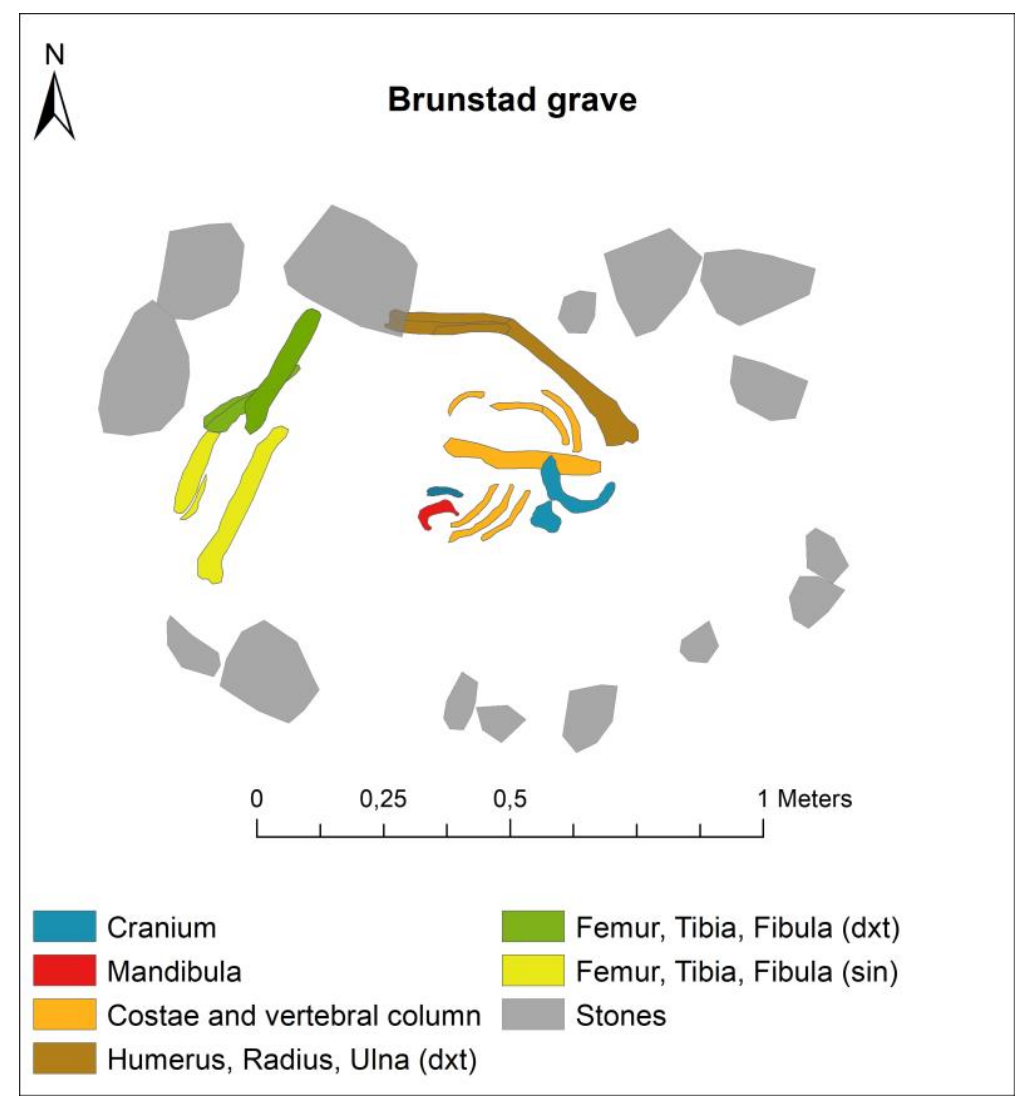

Fig. 7: Plan of the preserved bone elements. In some cases only parts of the depicted bones could be recovered ( $c f$. Supplementary material 2; Fig. 8 for bone imprints in the $3 D$ documentation). Only cranial fragments large enough to be plotted are shown here (Illustration: Kristin Eriksen, MCH, UiO). 
Biological sex could not be determined, but the size of the skeletal elements and the ratio between the diploe and the tabulae of the cranial fragments (cf. Gejvall, 1948; Sigvallius, 1994) indicate an adult individual. The preservation of the bones and the circumstances of their recovery limit any archaeothanatological observations (cf. Nilsson Stutz, 2003; Duday, 2009; Tõrv, 2016). The colourings of the soil from the unpreserved bone elements and the maintained anatomical articulations indicate that the burial contained a complete skeleton and it was interpreted as a primary deposition.

The position of the bones indicates that the body of the deceased was placed on its back, laid partly on the bedrock on the bottom of the grave pit (Fig. 7 and 8). The head was directed to the east and the legs were flexed at the hip and the knees were rotated upwards, towards the left side of the body. The 3D model (Fig. 8) shows the elevated position of the preserved fragments of the cranium and the flexed position of the femora, tibiae and fibulae, and the elevated position of the knees. It also demonstrates the position of the costal fragments and the possible remains of the spine. The elevated position of the cranial elements indicated that the upper part of the body was not placed on the floor of the grave, instead possibly bent forward in a raised or half-seated position. The position of the soil colourings of the spine and the preserved costal fragments could support this interpretation. The femora, tibiae and fibulae were recovered more or less directly on flat rock. In the earth blocks under and east of the cranial fragments, the floor of the pit was identified as a natural gravel layer (see Fig. 9). A seemingly empty space between the bones and the eastern inner wall of the grave pit was also observed (Fig. 7). This area constituted the shallowest part of the grave, and it was initially thought to contain preserved bone. However, no human bones were identified in this area of the grave. It is possible that the area contained an unpreserved object of organic material, for example antlers, as is known from other examples such as Skateholm in Sweden (Larsson, 1988: 128, 129). This object could have helped to support the upper part of the body in an elevated, i.e. half-sitting or leaning position, but this can neither be confirmed nor dismissed by the positioning of the bones. 


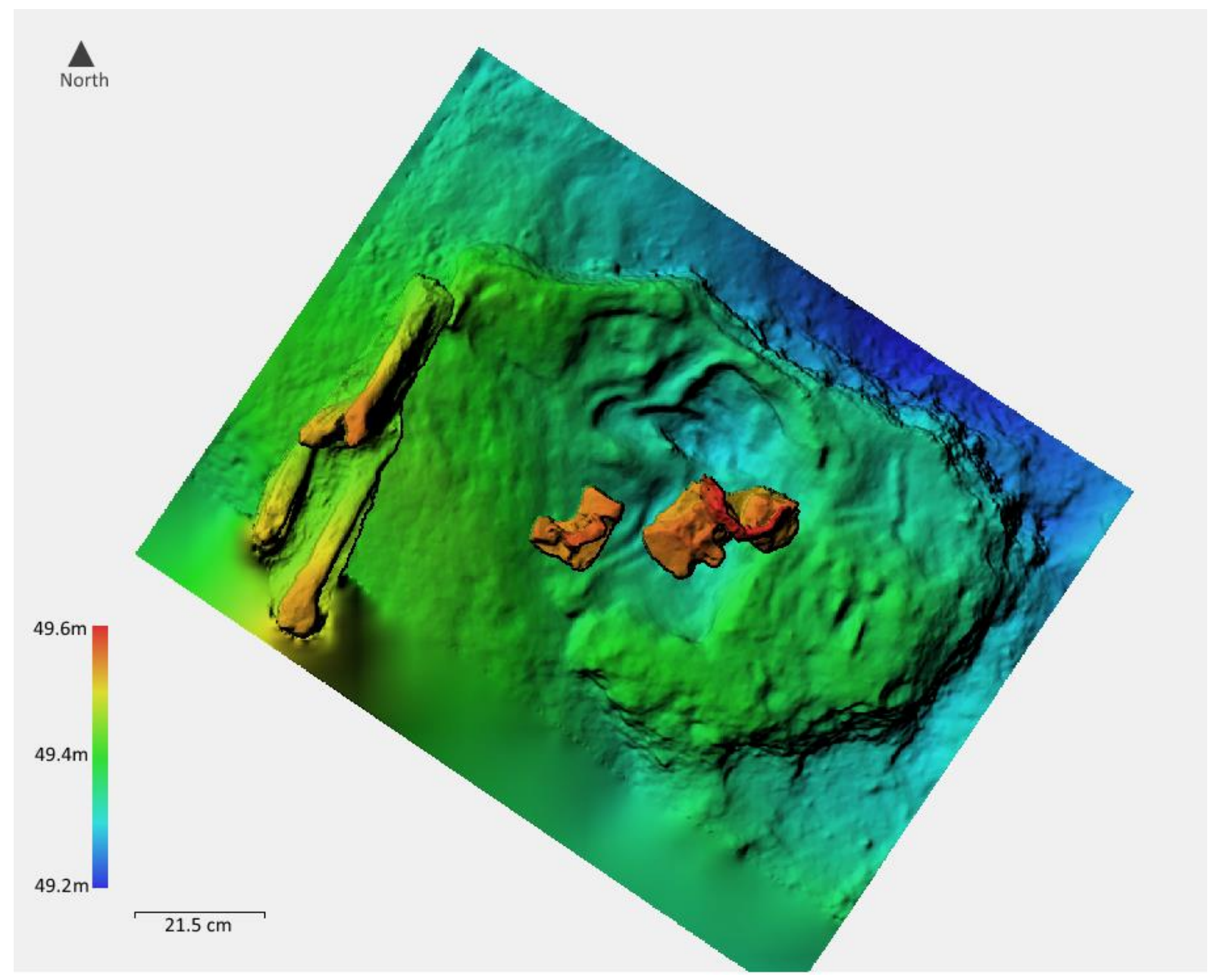

Fig. 8: The 3D model shows, top down, the preserved bone elements as well as imprints of bone material that could not be recovered due to poor preservation. The different colourings indicate the different heights of the bone elements in situ (cf. Fig. 7), in metres a.s.l.

(Illustration: Kristin Eriksen, $\mathrm{MCH}, \mathrm{UiO}$ ).

No teeth or enamel were recovered, which is otherwise common even if bone preservation is poor. But several cranial fragments were found in two concentrations (Fig. 7 and Fig. 9). The largest concentration was recovered in correct anatomical position in the area where the spinal column would have ended in the case of a half-seated or elevated position of the upper body. The other fragments were found about $20 \mathrm{~cm}$ to the west, in a slightly lower level at the thoracic region and together with the remains of the mandibula. 


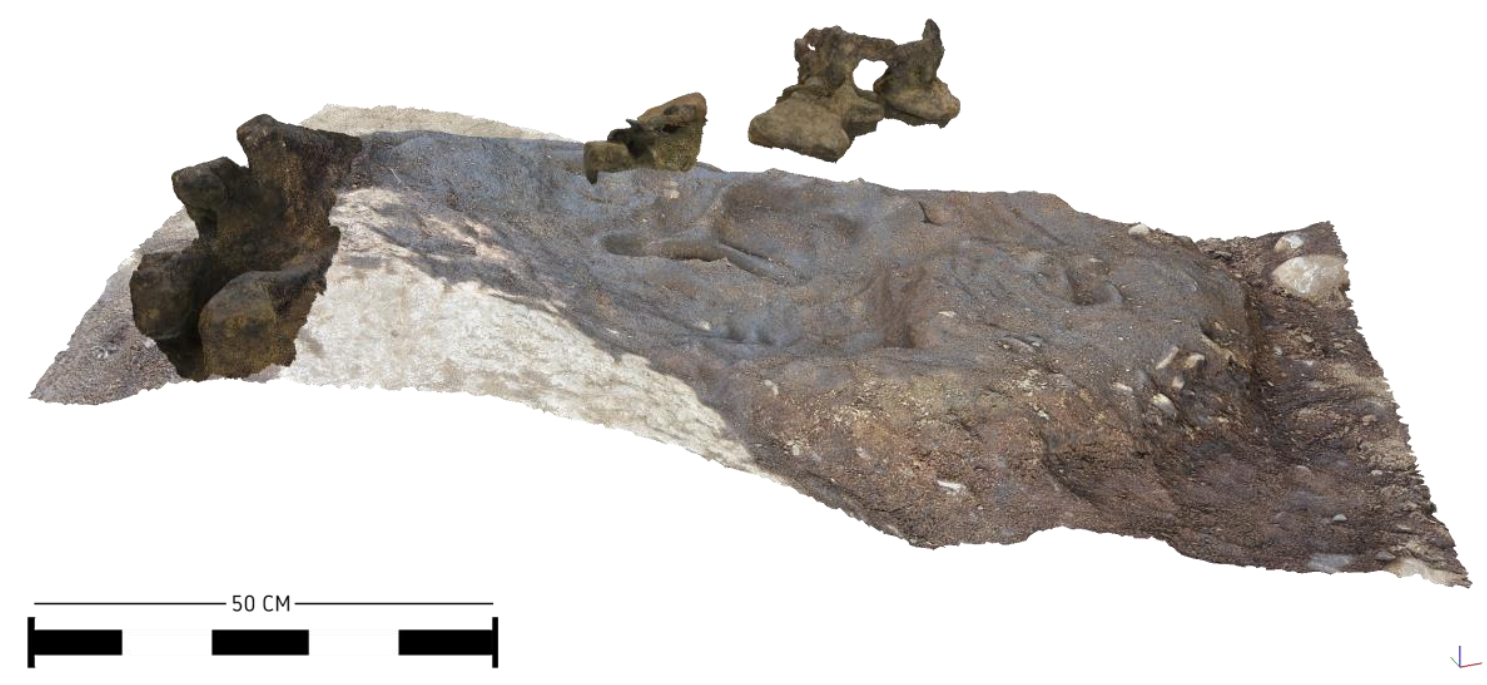

Fig. 9: 3D model of the burial from the side, looking towards the north. The two concentrations with fragments of the cranium and the mandibula are seen elevated from the bottom of the grave in the middle of the picture. Femora, tibiae and fibulae are seen on the left along the western side of the grave (compare Fig. 7 and 8). The model also shows the bedrock in the bottom of the grave to the west, and the beach pebbles on the bottom to the east (Illustration: Kristin Eriksen, $\mathrm{MCH}, \mathrm{UiO}$ ).

Fragments from both concentrations exhibit a similar morphology and ratio between the diploe and tabulae, so it is likely that the fragments originate from the same cranium. The mandibula is one of the first elements to disarticulate during decomposition (Micossi, 1991). It is thus possible that the mandibula collapsed forwards towards the bottom of the grave, descending within the initial space of the decomposing cadaver (cf. Nilsson Stutz, 2003: 266276, 2006). The cranial fragments may have moved together with the mandibula. Later disturbance, for example by burrowing animals, water, the collapse of an unidentifiable structure, earth pressure and growth of roots, or a combination of several factors, cannot be ruled out as factors for this displacement (cf. Duday, 2009).

The right arm, of which only small fragments of the humerus were preserved, was positioned alongside the body with the palm of the hand facing upwards, as indicated by the positioning of the ulna and the radius (Fig. 7). A heavy colouring suggests that the right hand was placed under the pelvis. No remains of the left arm (humerus, ulna or radius) or the bones of the left hand were recovered. The ribs, identified both as preserved fragments of costae and as soil 
colourings, were recovered in correct anatomical position (Fig. 7 and 8). Together with the preserved articulation of the lower arm, this supports the assumption that the space of decomposition was filled (see below). The preserved femora were flexed at the hip (the latter only identified as a soil colouring), they were tilted to the left and in (hyper) flexion at the knees. The position of the tibiae and fibulae suggests that the feet were placed under the pelvis. The position of the femora, the tibiae and the fibulae still projecting upwards during recovery, and with a small separation preserved between the right and left side, suggesting that the grave was progressively filled in by the surrounding sediments (cf. Duday, 2009), at least in the area of the legs (Fig. 9).

\subsection{Chronology}

Collagen preservation was not sufficient for radiocarbon-dating the bones. However, three pieces of charcoal from the burial pit, all from young branches, were radiocarbon-dated (Table 1; Fig. 10).

One charcoal sample (LuS-11115), dated to 6018-5845 cal BC (95\% confidence), comes from the sandy layer (layer 7) beneath the right arm bone. Two other samples (Beta-383181 and UBA-28737), dated to 5989-5846 and 5971-5731 cal BC (both 95\% confidence), come from the grave filling (see Fig. 6).

\begin{tabular}{|c|c|c|c|c|c|}
\hline Context & Material & $\begin{array}{l}\text { Quality of the } \\
\text { wood }\end{array}$ & $\begin{array}{l}\text { Laboratory } \\
\text { number }\end{array}$ & $\begin{array}{l}{ }^{14} \mathrm{C} \text { years } \\
\text { BP }\end{array}$ & $\begin{array}{l}\text { Calibrated } \\
\text { date range } \\
\text { (cal BC, } \\
95 \% \\
\text { confidence) }\end{array}$ \\
\hline \multicolumn{6}{|l|}{ Lok. 25} \\
\hline $\begin{array}{l}\text { Grave } \\
\text { A2400, } \\
\text { bottom }\end{array}$ & charcoal & $\begin{array}{l}\text { young branch } \\
\text { of Acer }\end{array}$ & LuS-11115 & $7060 \pm 45$ & $6018-5845$ \\
\hline $\begin{array}{l}\text { Grave } \\
\text { A2400, } \\
\text { layer } 6 / 7\end{array}$ & charcoal & $\begin{array}{l}\text { young branch } \\
\text { of Populus }\end{array}$ & UBA-28737 & $6943 \pm 44$ & $5971-5731$ \\
\hline $\begin{array}{l}\text { Grave } \\
\text { A2400, } \\
\text { layer } 5\end{array}$ & charcoal & not analysed & $\begin{array}{l}\text { Beta- } \\
383181\end{array}$ & $7030 \pm 30$ & $5989-5846$ \\
\hline $\begin{array}{l}\text { Hearth } \\
\text { A3185 }\end{array}$ & charcoal & $\begin{array}{l}\text { young branch } \\
\text { of Populus }\end{array}$ & UBA-28740 & $7067 \pm 37$ & $6019-5881$ \\
\hline $\begin{array}{l}\text { Hearth } \\
\text { A4663 }\end{array}$ & $\begin{array}{l}\text { burnt } \\
\text { hazelnut } \\
\text { shell }\end{array}$ & - & UBA-28743 & $7057 \pm 38$ & $6014-5848$ \\
\hline Cultural & charcoal & deciduous & UBA-28744 & $7032 \pm 34$ & $5992-5844$ \\
\hline
\end{tabular}




\begin{tabular}{|c|c|c|c|c|c|}
\hline $\begin{array}{l}\text { layer } \\
\text { A4604 }\end{array}$ & & $\begin{array}{l}\text { tree, older } \\
\text { branch }\end{array}$ & & & \\
\hline $\begin{array}{l}\text { Hearth } \\
\text { A3783 }\end{array}$ & charcoal & $\begin{array}{l}\text { Alnus/Corylus, } \\
\text { younger } \\
\text { branch }\end{array}$ & UBA-28745 & $6886 \pm 47$ & $5886-5728$ \\
\hline $\begin{array}{l}\text { Hearth } \\
\text { A4895 }\end{array}$ & charcoal & $\begin{array}{l}\text { deciduous } \\
\text { tree, younger } \\
\text { branch }\end{array}$ & UBA-28742 & $6920 \pm 37$ & $5880-5674$ \\
\hline \multicolumn{6}{|l|}{ Lok. 24} \\
\hline $\begin{array}{l}\text { Hearth } \\
\text { A4990 }\end{array}$ & charcoal & $\begin{array}{l}\text { Corylus, } \\
\text { younger } \\
\text { branch }\end{array}$ & UBA-28736 & $7439 \pm 39$ & $6400-6233$ \\
\hline $\begin{array}{l}\text { Hearth } \\
\text { A4979 }\end{array}$ & charcoal & $\begin{array}{l}\text { Corylus, } \\
\text { younger } \\
\text { branch }\end{array}$ & UBA-28735 & $7374 \pm 45$ & $6378-6097$ \\
\hline $\begin{array}{l}\text { Hearth } \\
\text { A4967 }\end{array}$ & charcoal & $\begin{array}{l}\text { deciduous } \\
\text { tree, } \\
\text { 5-year-old tree }\end{array}$ & UBA-28734 & $7285 \pm 37$ & $6226-6068$ \\
\hline $\begin{array}{l}\text { Sample } \\
50 x / 54 y \\
\text { NØ layer } \\
3\end{array}$ & charcoal & Corylus & Ua-4838 & $7090 \pm 35$ & $6026-5896$ \\
\hline $\begin{array}{l}\text { Hearth } \\
\text { A2574 }\end{array}$ & charcoal & $\begin{array}{l}\text { Salix/Populus, } \\
\text { younger } \\
\text { branch }\end{array}$ & UBA-28729 & $6948 \pm 35$ & $5967-5736$ \\
\hline $\begin{array}{l}\text { Hearth } \\
\text { A4200 }\end{array}$ & charcoal & $\begin{array}{l}\text { Fagus, } \\
\text { younger } \\
\text { branch }\end{array}$ & UBA-28732 & $6873 \pm 43$ & 5869-5665 \\
\hline $\begin{array}{l}\text { Sample } \\
50 x / 54 y \\
\text { layer } 2\end{array}$ & charcoal & Betula & Ua-48381 & $6850 \pm 35$ & $5833-5661$ \\
\hline
\end{tabular}

Table 1: AMS radiocarbon dates from Brunstad lok. 24 and lok. 25. Calibrated results obtained using OxCal v4.3 (Bronk Ramsey, 2009) and IntCall3 atmospheric curve (Reimer et al., 2013). For discussion see also section 3.5.

The filling most likely represents dug-out material from the grave pit, and material from an existing settlement horizon at the spot. A reliable terminus ante quem for inhumation and filling is however represented by a charcoal sample from the hearth $A 3185$, which cut the top of the grave structure on its southern side (Fig. 6, layer 3). Fire-cracked stones and large amounts of charcoal indicate the burning of a fire on the spot. The sample (UBA-28740) is dated to 6019-5881 cal BC (95\% confidence). 
These similar and overlapping four dates (see also Fig. 10) indicate that the settlement horizon, the burial and the hearth were chronologically relatively closely related, probably used/constructed not more than a few years apart.

\subsection{A peat fire on top of the grave?}

Four of six pollen samples taken from the cross-section (Fig. 6) contained enough material for analysis. The pollen composition in the grave filling (samples 3 and 4) and in the topsoil (sample 6) point to open vegetation in the vicinity, with grasses and sedges and some wet ground, and a tree-cover of about 25-30\%. Sample 5, from the edge of hearth A3185, however, indicates moor vegetation dominated by heather (Nielsen and Moltsen, 2015). This marked shift may reflect either an intentional change of the vegetation at the location to a heather-dominated plant cover, for example, by burning off the land, or the possibility that the sediment that was sampled originated from another pollen source area (Nielsen and Moltsen, 2015). In the light of the overlapping radiocarbon dates from the grave filling and the hearth, the second explanation is regarded as most likely, not least since the development of heather vegetation would have taken longer. Wetland sediments from another location may have been brought to and processed in the hearth, perhaps as peat for burning.

\subsection{The burial and its context - reconstruction of a sequence of events}

The spatio-temporal context of the burial allows the reconstruction of a sequence of events and intentional activities at Brunstad, including the mortuary practices in connection with the burial (compare Table 1, Fig. 10 and Fig. 2). 


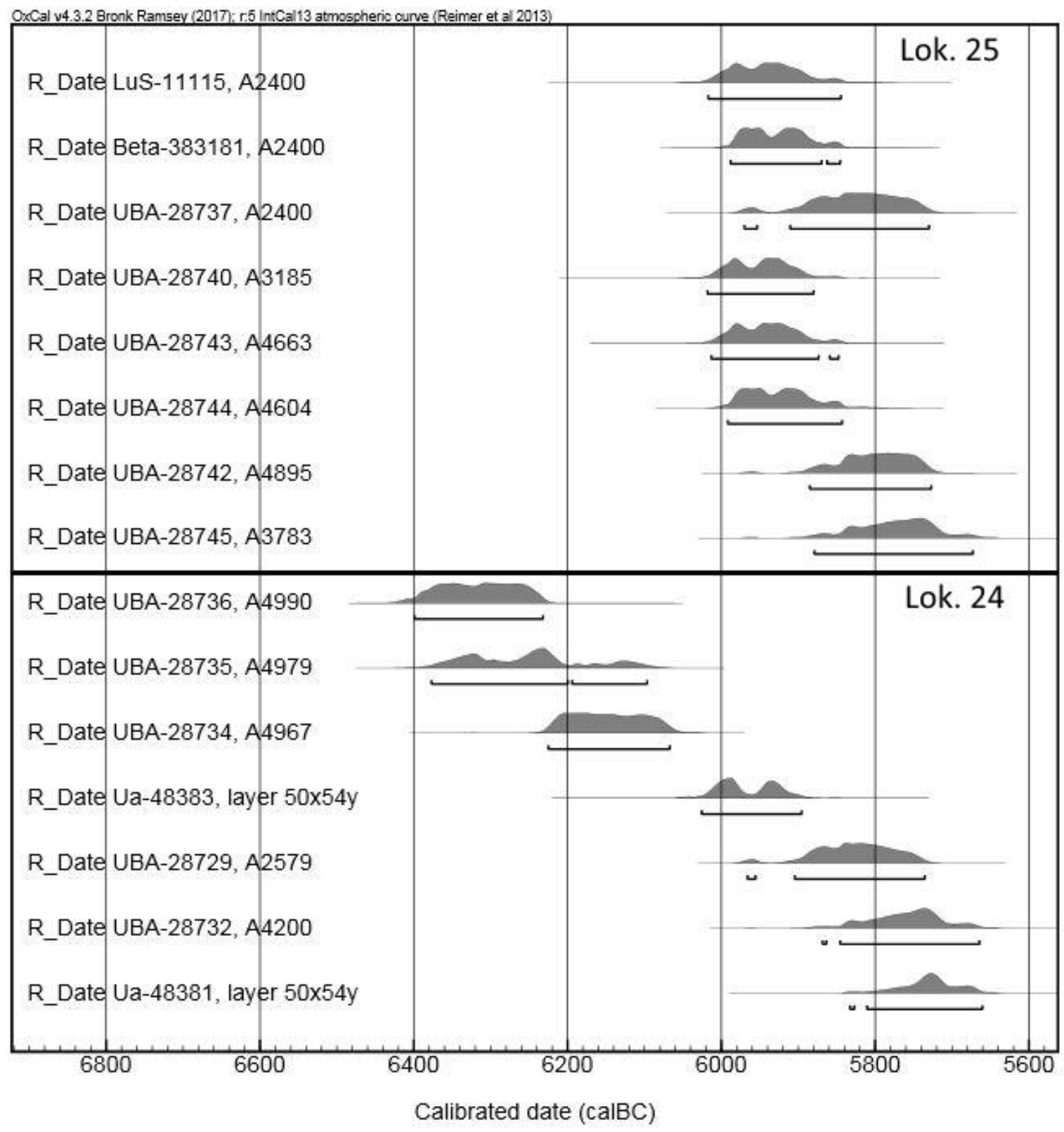

Fig. 10: Plot of the AMS radiocarbon dates from Brunstad lok. 25 and lok. 24 with the calibrated date ranges ( $c f$. Table 1).

Lok. 24 to the east was visited repeatedly between $c .6400$ and 5700 cal BC (UBA-28736, UBA-28735, UBA-28734, UBA-28729, UBA-28732, Ua-48383, Ua-48381 - all 95\% confidence). The earliest evidence of human activity at lok. 25 dates to $c .5900$ cal BC, including the charcoal in the filling of the grave $A 2400$ and the associated hearth $A 3185$ (see section 3.3), as well as hearth $A 4663$ and the cultural layer $A 4604$, which both were located just a few metres to the south (UBA-28743, UBA-28744 - 95\% confidence). The temporal relations of these features cannot be pinned down in more detail. The grave's placement close to the shore and on an existing settlement site seems to have been carefully chosen, at a 
location that provided sediments which were thick enough to dig a deep pit. Furthermore, its placement right between two elongated outcrops might indicate a spatial conception which on this occasion valued symmetry; it might not be pure coincidence that the location of the excavation's profile trench, which was set up right in the middle of the location, cut one half of the grave. Dug down to natural rock, the grave pit was dimensioned for the inhumation of an adult person in a flexed position. The body was placed in the grave, possibly in articulation, sometime soon after death. It was east-west-oriented with the head and the upper body, most likely in half-sitting position, to the east and with the flexed legs drawn up towards the western edge of the grave pit. The body was covered with a layer of sand, above which scattered stones were placed, and the pit was filled in with dug-out masses. Slightly later, either as part of the burial procedure or in connection with a revisit to the site, a hearth was constructed on top of the grave. The fire, probably fired with peat, might have had both ritual and practical significance (Grünberg, 2000: 151), such as heating, preparing food or drinks, or the burning and transformation of materials by fire or light.

Some metres to the north, two hearths, $A 3783$ and $A 4895$, dated to 5886-5728 and 5880-5674 cal BC (UBA-28745, UBA-28742 - 95\% confidence), bear witness to later activities on the site. The radiocarbon dates indicate an abandonment of these sites before $5500 \mathrm{BC}$, at a time when the former shore to the north of the site became a dry plain due to the isostatic uplift.

\section{Discussion: Special or norm? Mesolithic mortuary practices in a persistent location}

\subsection{Supra-regional features of the Brunstad burial}

The Brunstad burial exhibits features which can be recognized in graves from South Scandinavia and other parts of Europe (cf. Bugajska, 2014; Grünberg, 2016). These include aspects of location such as the vicinity to a contemporary camp site or settlement (Grünberg, 2000: 23-24; Brinch Petersen, 2015: 88), and the placement on the shore (Nilsson Stutz, 2014; Meiklejohn et al., 2016). Also, the location on a small island is common (e.g. Schulting, 1996; Sørensen, 2016), such as along the southern and western Swedish coast (Larsson, 1988: 52-53; Sjögren and Ahlström, 2016).

Similarities can also be observed with regard to the position of the body in the grave.

Flexed, sitting or leaning body positions of different types are known from Mesolithic burials all over Europe (Grünberg, 2008). In Sweden they occur at sites with many burials like Skateholm and Strandvägen (Larsson, 1988; Nilsson Stutz, 2003; Gummesson and Molin, 2016), but also in isolated graves (e.g. Sjögren and Ahlström, 2016; Alexandersson et al., 2018). Burials displaying similar body positions to that of the Brunstad burial, with flexed 
knees and hips, although often placed lying on their lateral side, are known from examples like Skateholm I (Nilsson Stutz, 2003: Photo 3 and 8) and from Strandvägen (Gummesson and Molin, 2016), but also from the Baltic region, e.g. from Tamula in Estonia (Tõrv, 2016: 184, 334). Individuals buried with flexed knees and hips, and placed on their backs, are also documented both from Strandvägen and Tamula, but in these cases flexion was not as vigorous as at Brunstad. Hyperflexion of the knees and hips, preserved in a projecting position, has been recorded in Mesolithic burials from Portugal (Peyroteo Stjerna, 2016: 222, 244, 353). Hyperflexion of solely the knees and extension of the hips (i.e. leg placed underneath the body) is, on the other hand, known from Tamula (Tõrv, 2016: 277, 334). Preservation is a factor that needs to be considered in regard to any comparisons of body positions. The maintenance of the bones in an elevated position, for example, is due to both the initial position and the nature of the surrounding sediments (Duday, 2009). Variations of body positions seem to be part of the common practices for inhumations during the Mesolithic period (Nilsson Stutz, 2003: 324; Tõrv, 2016: 324).

The construction of hearths on top of or in close connection to Mesolithic burials is also reported from other sites in Europe (Grünberg, 2000: 151-152), and has been interpreted as connected to the burial ritual - as at Téviec in Brittany, France (Péquart et al., 1937: 21-24; David 2016, Fig. 2), Mszano in Poland (Marciniak, 2001; Sulgostowska, 2016), Donkalnis Island in Lithuania (Butrimas, 2016,: 204), at Popovo, Northern Russia (Oshibkina, 2016), Vlasac in Serbia (Srejović and Letica, 1978), and at the dog grave (grave 23) at Skateholm I in Sweden (Larsson, 1982).

\subsection{The regional context}

In a Norwegian context, Brunstad stands out as a rare Mesolithic open-air site with an inhumation. The other Norwegian finds of human remains, which might give insights into Mesolithic burial practices, mostly originate from caves. Some of them stem from wetlands or submerged sites. 
1 Hummervikholmen, Vest-Agder county

2 Bleivik, Rogaland county

3 Viste, Rogaland county

4 Brunstad, Vestfold county

5 Uleberg (Bohuslän, Sweden)

6 Grønehelleren, Sogn and Fjordane county

7 Gropbakken, Finnmark county

8 Steigen, Nordland county

9 Storbåthelleren, Nordland county

10 Sømmevågen, Rogaland

11 Torpum 9b, $\emptyset$ stfolg county

12 Sævarhelleren, Hordaland

13 Skipshelleren, Hordaland

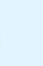

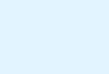

(2)

(2)

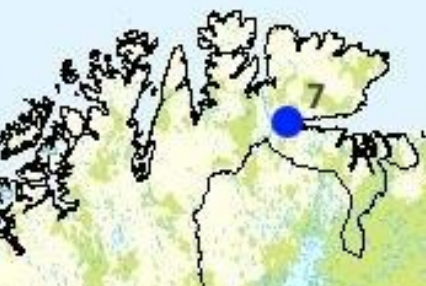

THE

NORTH

SEA

$100 \mathrm{~km}$

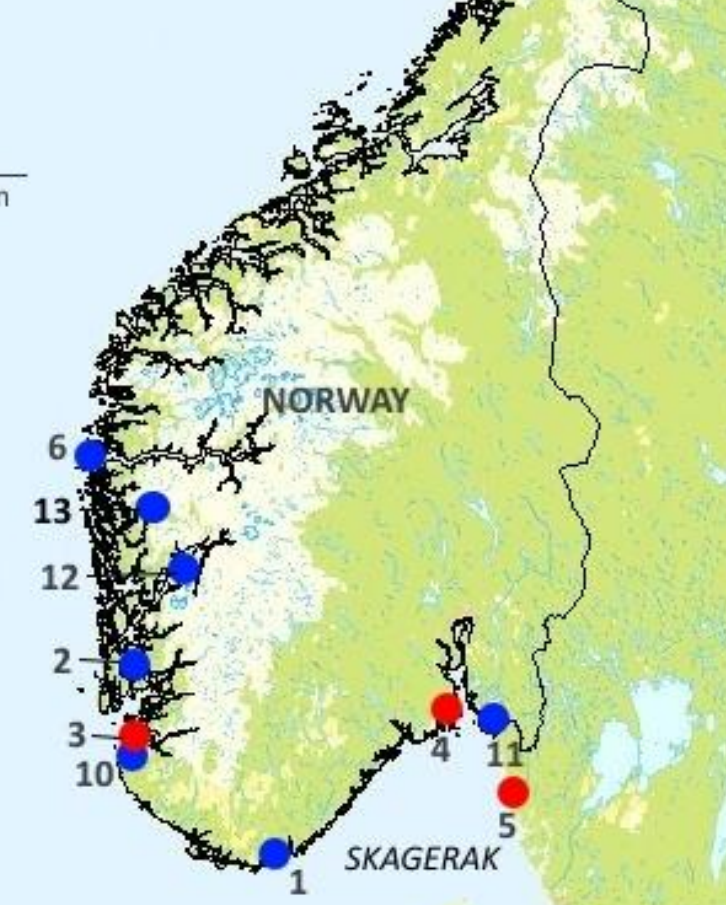

Fig. 11: Confirmed sites with human bones from Norway that date to the Mesolithic period (in blue). The sites Brunstad and Viste, South Norway, and Uleberg, Western Sweden, are marked in red. They are dated to the centuries around $6000 \mathrm{cal} B C$ and exhibit single lying burials with the deceased deposited in flexed position (Map: Almut Schülke, MCH, UiO). 
These encompass the remains of several individuals found underwater at Hummervikholmen (Fig. 11, No. 1) (Skar et al., 2016), and the remains of a man from a bog at Bleivik (Fig. 11, No. 2) (Lie, 1985; Indrelid, 1996: 53), and date to the Middle Mesolithic period (8200-6400 cal BC). Mortuary evidence from the Late Mesolithic period encompasses finds from Western Norwegian caves, such as the juvenile individual in flexed position from Viste (Fig. 11, no. 3), dated to $c .6100 \mathrm{cal}$ BC (Fürst, 1909; Schulting et al., 2016), and the remains of several individuals from Grønehelleren (Fig. 11, no. 6), dated to c. 5000 cal BC (Indrelid, 1996: 53; Bergsvik and Storvik, 2012: 27). A recently found inhumation at Sømmevågen in Western Norway (Fig. 11, no. 10) dates to the latest part of the period, c. 4400 cal BC (Denham, 2016). From the same Late Mesolithic site isolated human bones have been recovered (Denham, 2016). Isolated human bones were also found at the Late Mesolithic site at Torpum $9 \mathrm{~b}$ in Eastern Norway (Fig. 11, no. 11) (Tørhaug, 2003) and in the Western Norwegian caves Sævarhelleren and Skipshelleren (Fig. 11, no. 12, 13) (Bergsvik and Storvik, 2012). Hundreds of kilometres to the north three sites in Northern Norway have yielded human bones. In Gropbakken in Finnmark (Fig. 11, no. 7) three inhumations in stone mounds dating to around 5100 cal BC have been recorded (Simonsen 1961: 180; Olsen 1994: 78-88), while two caves, Steigen and Storbåthelleren (Fig. 11, no. 8, 9), have yielded skeletal material respectively dating to c. $4300 \mathrm{cal} \mathrm{BC} \mathrm{(Günther} \mathrm{et} \mathrm{al.} \mathrm{2018)} \mathrm{and} 4000$ cal BC (Utne 1971; Johansen et al. 1986).

These Norwegian finds, covering a period of several thousand years, seem at once few and random. However, even for the rather large number of Mesolithic burials in Europe - more than 2000 graves from about 250 sites/grave fields are currently known (Grünberg, 2016; Grünberg et al., 2016) - it has lately become more and more evident that they cannot, even considering poor preservation conditions, represent the entire Mesolithic population (Nilsson Stutz, 2014; Gramsch, 2016). Beside inhumations, other burial practices and handling of human remains were practised, as the evidence of cremations, and the finds of isolated human bones in settlement contexts indicate (Bugajska, 2014: 69; Brinch Petersen, 2016; Sjögren and Ahlström, 2016; Gummesson et al., 2018). In addition, ethnographic parallels attest to a variety of practices beyond inhumation in hunter-gatherer groups, which would be difficult to trace in the archaeological record; for example the deposition of corpses on platforms or in hollow trees, and the dismemberment and/or defleshing of bodies with the subsequent use and display of specific body parts (Knutsson, 1995: 29-67; Struwe, 2016; Brinch Petersen, 2016). Disturbances in Mesolithic burials as conscious components of the funerary practices have been inferred (Gray Jones, 2011; Nilsson Stutz and Larsson, 2016; Bugajska, 2016). It has 
been suggested that some of these practices actually might be depicted in the Mesolithic rock art of Western Norway (Lødøen, 2015). Taking this into account, it is likely that the Norwegian Mesolithic burial evidence might reflect a similar variety of practices of handling and disposal of the dead, most of them unidentified in the archaeological record. The mortuary practice pursued at Brunstad, with components such as the digging of a grave pit, the body position of the deceased, and the sealing of the grave with stones, were perhaps only chosen in certain cases. Different factors could have influenced such a choice, for example the social status of the deceased, or the circumstances or location of death (Grünberg, 2008, 2016). Sitting or half-lying burial positions might have had cross-cultural or regional meaning (Grünberg, 2008), but the reasons for which types of burial were selected also might have changed from region to region and through time (Bugajska, 2014). The other two isolated Late Mesolithic finds of individuals in flexed body positions, at Viste and Uleberg, could be other examples of such special burial practices in Southern Norway and Western Sweden at the time (cf. Fig. 11).

\subsection{A single grave in a persistent place: Coincidence or intention?}

The detailed chronology of larger burial sites in Scandinavia and in other areas in the Baltic region shows that these sites evolved grave by grave throughout the centuries (e.g. Zagorska, 2006; Brinch Petersen, 2015; Gummesson and Molin, 2016). These burial grounds are considered important places, to which people returned and which were reused repeatedly over long periods of time (Ahola, 2017; Larsson et al., 2018; Fahlander, 2008). The Brunstad site, however, did not evolve into a long-term burial ground, despite clear evidence that it was revisited some generations after the grave was constructed. This might be explained in several ways. In all cases the question is central whether the memory of the burial was still alive. Ethnographic parallels attest that hunter-gatherers often did not return to places at which people had been buried, and that later burial(s) at the same site were due to the general suitability of the place, while the earlier burial(s) were unknown (Littleton, 2007). The fact that the Brunstad site was not turned into a grave field could be interpreted in this sense. The later revisits would then indicate that the site generally was considered suitable for a stay. However, the single grave could also be a result of a situation where mobility patterns that in principle aimed at revisiting the site, and maybe burying other persons there, in the sense of persistent and remembered places, were halted for some reasons. The placement of the grave has to be understood in the context of the semi-sedentary societies that inhabited the area at the time (Glørstad, 2010). The background, history, character and rhythm of their mobility has 
to be studied more closely in order to understand how memory, and with it the meaning of places, was transferred within groups or from group to group (see e.g. Littleton, 2007). The fact that the few known Late Mesolithic burials from Norway and Western Sweden are isolated graves could also hint at a distinct mode of burial in special cases in this area. In such a case the special nature of these graves - compared to other burial practices which did not involve inhumation - might have prevented later burials at the sites. This site was obviously considered appropriate for an inhumation, not only regarding its natural conditions with regard to the sediments being deep enough, but most likely also in terms of the social and cosmological settings. It is important to consider that the event of death either on-site or offsite would have required different preparations and rituals, with the latter including a transport of the corpse to the island.

The construction of the grave reinforced the meaning of the site within the landscape, but also changed it by connecting the memory of the deceased and the burying community to the place - which either would have led to a temporary abandonment of the site, or to targeted revisit(s). The question remains when and how the memory of the grave ceased, and if the documented revisit(s) were related to the remembrance of this specific burial.

\section{Conclusion}

The similarities of the Brunstad burial to other Mesolithic burials in Scandinavia and beyond indicate that the burying community shared cultural practices with other hunter-gatherer communities over large geographical distances during the Late Mesolithic period. Against the background of the evidence from Middle and Northern Scandinavia, the burial is a rare specimen of an inhumation in a meticulously constructed grave in the region. The placement in a carefully selected location and the flexed body position might indicate that the burial was special at the time, either due to the circumstances of death, on the 'right' site, or because the deceased person, in the given social context, required this form of burial.

\section{Acknowledgements}

We would like to thank two anonymous referees for constructive and thorough comments on an earlier version of the manuscript. 


\section{References}

Ahola, M., 2017. Memory, landscape \& mortuary practice. Understanding recurrent ritual activity at the Jönsas Stone Age cemetery in Southern Finland. Acta Archaeologica 88, 95120.

Alexandersson, K., Andersson, A.-K., Papmehl-Dufay, L., 2018. Facing the sea: A Mesolithic burial at Vannborga, Öland, Sweden. Mesolithic Miscellany 26(1), 3-13.

Bergsvik, K.A., Storvik, I. 2012. Mesolithic Caves and Rockshelters in Western Norway, in Bergsvik, K.A., Skeates, R. (Eds.), Caves in Context. The Cultural Significance of Caves and Rockshelters in Europe. Oxford: Oxbow, pp. 22-38.

Brinch Petersen, E., 2015. Diversity of Mesolithic Vedbaek. Acta Archaeological Vol. 86(1). Oxford: Wiley.

Brinch Petersen, E., 2016. Afterlife in the Danish Mesolithic - the creation, use and discarding of "Loose Human Bones", in Grünberg et al., 2016: pp. 47-62.

Bronk Ramsey, C., 2009. Bayesian analysis of radiocarbon dates. Radiocarbon 51(1), 337360. https://doi.org/10.1017/S0033822200033865

Bugajska, K., 2014. Burial practices of hunter-gatherers in the Stone Age of southern Scandinavia and the Middle European plain. Przeglad Archaeologiczny 62, 5-69.

Bugajska, K., 2016. In the Ground or in the Basket? Burial Wrappings from the Stone Age Hunter's Cemetery at Dudka, Masuria, NE-Poland. Novensia 26, 9-23.

Butrimas, A., 2016. Biržulis Lake islands Donkalnis and Spiginas Mesolithic cemeteries (West Lithuania), in Grünberg et al., 2016: 193-217.

David, E., 2016. The bone pins from Téviec (Morbihan, France) illuminate Mesolithic social organisation, in Grünberg et al., 2016: 609-628.

Denham, S., 2016. Beinmaterialet fra Sømmevågen. Frá haug og heiðni 2016(2), 13-17. 
Duday, H., 2009. The Archaeology of the Dead: Lectures in Archaeothanatology. Translated by Anna Maria Cipriani and John Pearce. Oxford: Oxford University Press.

Fahlander, F., 2008. A piece of the Mesolithic. Horizontal stratigraphy and bodily manipulation at Skateholm, in Fahlander, F., Oestigaard, T. (Eds.), The materiality of death. Bodies, burials, beliefs. Oxford: BAR International Series 1768, pp. 29-45.

Fretheim, S., 2017. Mesolithic dwellings. An empirical approach to past trends and present interpretations in Norway. Doctoral thesis NTNU. Trondheim.

Fürst, C.N., 1909. Das Skelett von Viste auf Jäderen. Kristiania: Jacob Dybwad.

Gejvall, N.-G., 1948. Bestämningar av de brända benen från gravarna i Horn. In Salström, K. E., Gejvall, N.-G., Gravfältet på Kyrkbacken i Horns socken, Västergötland. Stockholm: Wahlström \& Widstrand.

Glørstad, H., 2004. Noen tanker om kulturforhold på bakgrunn av undersøkelsene ved Svinesund, in Glørstad, H. (Ed.), Oppsummering av Svinesundsprosjektet. Varia 57. Oslo: Universitetets Kulturhistoriske Museer, Fornminneseksjonen, pp. 59-81.

Glørstad, H., 2010. The structure and history of the Late Mesolithic societies in the Oslo fjord area 6300-3800 BC. Lindome: Bricoleur press.

Gramsch, B., 2016. The Mesolithic burials of North-Eastern Germany - synopsis and new aspects, in Grünberg et al., 2016: 385-400.

Gray Jones, A., 2011. Dealing with the dead: manipulation of the body in the mortuary Practices of Mesolithic North West Europe. PhD dissertation. Manchester University.

Green, S., Bevan, A., Shapland, M., 2014. A comparative assessment of structure from motion methods for archaeological research. Journal of Archaeological Science 46, 173-181. https://doi.org/10.1016/j.jas.2014.02.030 
Grünberg, J.M., 2000. Mesolithische Bestattungen in Europa. Ein Beitrag zur vergleichenden Gräberkunde. Internationale Archäologie 40. Rahden/Westfalen: Marie Leidorf GmbH.

Grünberg, J.M., 2008. Aufrecht ins Jenseits: Die sitzende Haltung von Verstorbenen im Mesolithikum. Die Kunde N.F. 59, 39-90.

Grünberg, J.M., 2016. Mesolithic burials - Rites, symbols and social organisation of early post-glacial communities, in Grünberg et al., 2016: 13-24.

Grünberg, J.M., Gramsch, B., Larsson, L., Orschiedt, J., Meller, H. (Eds.), 2016, Mesolithic burials - Rites, symbols and social organisation of early postglacial communities. International Congress Halle (Saale), Germany, 18th-21st September 2013. Halle: Landesmuseum für Vorgeschichte.

Günther, T., Malmström, H., Svensson, E. M., Omrak, A., Sánchez-Quinto, F., Kılınç, G. M. Krzewińska, M., Eriksson, G., Fraser, M., Edlund, H., Munters, A. R., Coutinho, A., Simões, L. G., Vicente, M., Sjölander, A., Sellevold, B. J., Jørgensen, R., Claes, P., Shriver, M. D., Valdiosera, C., Netea, M. G., Apel, J., Lidén, K., Skar, B., Storå, J., Götherström, A., Jakobsson, M. (2018). Population genomics of Mesolithic Scandinavia: Investigating early postglacial migration routes and high-latitude adaptation. PLOS Biology 16(1). https://doi.org/10.1371/journal.pbio.2003703

Gummesson, S., Hallgren, F., Kjellström, A., 2018. Keep your head high: skulls on stakes and cranial trauma in Mesolithic Sweden. Antiquity 92, 74-90.

https://doi.org/10.15184/aqy.2017.210

Gummesson, S., Molin, F., 2016. The Mesolithic Cemetery at Strandvägen, Motala, in eastern central Sweden, in Grünberg et al., 2016: 145-159.

Henningsmoen, K. 1979. En karbon-datert strandforskyningskurve fra Søndre Vestfold, in Nydal, R., Westin, S., Hafstein, U., Gulliksen, S. (Eds.), Fortiden i søkelyset. 14C-datering gjennom 25 år. Trondheim: Laboratoriet for radiologisk datering, 239-247. 
Indrelid, S., 1996. Frå steinalder til vikingetid. Strilesoga: Nord og Midhordaland gjennom tidene 1. Bergen: Eide forlag.

Jaksland, L., 2001. Vinterbrolokalitetene - en kronologisk sekvens fra mellom- og senmesolitikum i Ås, Akershus. Varia 52. Oslo: Universitetets Kulturhistoriske Museer, Oldsaksamlingen.

Johansen, O. S., Gulliksen, S., Nydal, R., 1986. $\delta \mathrm{C} 13$ and diet: Analysis of Norwegian human skeletons. Radiocarbon 28, 754-761. https://doi.org/10.1017/S0033822200007992

Kjällkvist, M., 2001. Gåvor eller avfall? En studie av sex mesolitiska gravar från Tågerup, in Karsten, P., Knarrström, B. (Eds.), Tågerup specialstudier. Skånska spår - arkeologi längs Västkustbanan. Lund: Riksantikvarieämbetet, 32-79.

Knutsson, H., 1995. Slutvandrat? Aspekter på övergången från rörlig till bofast tillvaro. Uppsala: Societas Archaeologica Upsaliensis.

Larsson, L., 1982. Skateholmsprojektet. Nya gravar och ett nytt gravfält från jägarstenåldern. Limnhamnia 24, 11-41.

Larsson, L., 1988. Ett fångstsamhälle för 7000 år sedan. Boplatser och gravar i Skateholm. Kristianstad: Signum.

Larsson, L., 2016. Final comments, in Grünberg et al., 2016: 903-907.

Larsson, L., Nilsson Stutz, L., Zagorska, I., Bērziņš, V., Ceriņa, A., 2018. New aspects of the Mesolithic-Neolithic cemeteries and settlement at Zvejnieki, Northern Latvia. Acta Archaeologica 88, 58-93. https://doi.org/10.1111/j.1600-0390.2017.12177.x

Lie, R.W., 1985. Ældste Nordmand. Skalks Gastebog. Wormianum 1985, 47-50.

Littleton, J., 2007. From the perspective of time: hunter-gatherer burials in south-eastern Australia. Antiquity 81, 1013-1028. https://doi.org/10.1017/S0003598X00096083 
Lødøen, T., 2015. Treatment of corpses, consumption of the soul and production of rock art: Approaching Late Mesolithic mortuary practices reflected in the rock art of Western Norway. Fennoscandia archaeologica 32, 79-99.

Marciniak, M., 2001. The burial ritual cemetery from the Boreal period in Mszano, Brodnica district. Fontes archaeologici Posnanienses, 39, 95-123.

Meiklejohn, C., Babb, J., Hiebert, W., 2016. A chrono-geographic look at Mesolithic burials: an initial study, in Grünberg et al., 2016: 25-45.

Micossi, M., 1991. Postmortem Change in Human and Animal Remains. Springfield: Thomas.

Mikkelsen, E., 1975. Mesolithic in South-Eastern Norway. Norwegian Archaeological Review 8, 19-35. https://doi.org/10.1080/00293652.1975.9965220

Nielsen, A.B., Moltsen, A. S. S., 2015. Pollen- og makrofossiler fra Brunstad konferencecenter Sag 10/5450. Natur og Kultur-rapport nr. 23-2015, Copenhagen.

Niklasson, N., 1932. Ett bidrag til kännedomen om begravningsskicket under stenåldern.

Bidrag til kännedomen om Göteborgs og Bohusläns fornminnen och historia 1932, 211-223.

Nilsson Stutz, L., 2003. Embodied Rituals \& Ritualized Bodies. Tracing Ritual Practices in Late Mesolithic Burials. Acta Archaeologica Lundensia Series in $8^{\circ}$, No. 46. Lund: Almqvist \& Wiksell International.

Nilsson Stutz, L., 2006. Setting it Straight. A re-analysis of the Mesolithic Barum burial according to the principles of Anthropologie 'de terrain'. Lund Archaeological Review 11-12, $37-46$.

Nilsson Stutz, L., 2014. Mortuary practices, in Cummings, V., Jordan, P., Zvelebil, M. (Eds.), The Oxford handbook of the archaeology and anthropology of hunter-gatherers. Oxford: Oxford University Press, pp. 712-728. 
Nilsson Stutz, L., Larsson, L., 2016. Disturbing the dead. Archaeothanatological analysis of the Stone Age burials at Zvejnieki, Latvia (excavated 2006-2009). Journal of Archaeological Science Reports 10, 715-724. https://doi.org/10.1016/j.jasrep.2016.06.034

Nordqvist, B., 2000. Coastal adaptations in the Mesolithic. A study of coastal sites with organic remains from the Boreal and Atlantic periods in Western Sweden. Göteborg: Göteborg University, Department of Archaeology.

B. Olsen 1994, Bosetning og samfunn i Finnmarks forhistorie, Troms $\emptyset$ : Universitetsforlaget.

Oshibkina, S., 2016. Funeral rituals of the population of the Eastern Lake Onega region (based on materials from Popovo and Peschanitza cemeteries). In Grünberg et al., 2016: 793808.

Persson, P., 2008. Nauen 5.2 - Stenålderboplatser och fossil åkermark, In Gjerpe, L.E. (ed.), Steinalderboplasser, boplasspor, graver og dyrkningsspor. E18-prosjektet Vestfold, Bind 2. Varia 72. Oslo: Kulturhistorisk museum, Fornminneseksjonen, 163-198.

Péquart, M., Péquart S.-J., Boule, M., Vallois, H., 1937. Téviec. Station-nécropole mésolithique du Morbihan. Archives de l'Institut de Paléontologie Humaine. Paris: Masson et Cie Editeurs.

Peyroteo Stjerna, R., 2016. Death in the Mesolithic or the Mortuary practices of the Last Hunter-Gatherers of the South-Western Iberian Peninsula, $7^{\text {th }}-6^{\text {th }}$ Millennium BCE. Occasional Papers in Archaeology 60. Uppsala: Uppsala Universitet.

Reimer, P.J., Bard, E., Bayliss, A., Warren Beck, J., Blackwell, P. G., Bronk Ramsey, C., Buck, C.E., Cheng, H., Edwards, R.L., Friedrich, M., Grootes, P.M., Guilderson, T.P., Haflidason, H., Hajdas, I., Hatté, C., Heaton, T.J., Hoffmann, D.L., Hogg, A.G., Hughen, K.A., Kaiser, K.F., Kromer, B., Manning, S.W., Niu, M., Reimer, R.W., Richards, D.A., Scott, E.M., Southon, J.R., Staff, R.A., Turney, C.S.M., van der Pflicht, J., 2013. IntCal 13 and Marine13 Radiocarbon Age Calibration Curves 0-50,000 Years cal. BP. Radiocarbon 55, 1869-1888. https://doi.org/10.2458/azu_js_rc.55.16947 
Reitan, G., 2016. Mesolittisk kronologi i Sørøst-Norge - et forslag til justering. Viking 79, $23-51$.

Schulting, R., 1996: Antlers, bone pins and flint blades: the Mesolithic cemeteries of Téviec and Hoëdic, Brittany. Antiquity 70, 335-350. https://doi.org/10.1017/S0003598X00083319

Schulting, R., Budd, C., Denham, S. 2016. Re-visiting the Viste Skeleton, western Norway. Mesolithic Miscellany 24.1, 22-27.

Simonsen, P. 1961, Varangerfunnene II. Troms $\varnothing$ Museums skrifter VII:2. Troms $\varnothing$ : Troms $\emptyset$ museum.

Sjögren, K.G., Ahlström, T., 2016. Early Mesolithic burials from Bohuslän, western Sweden, in Grünberg et al., 2016: 125-143.

Skar, B., Lidén, K., Eriksson, G., Sellevold, B., 2016. A submerged Mesolithic grave site reveals remains of first Norwegian seal hunters, in Bjerck, H., Breivik, H. M., Fretheim, S. E., Piana, E. L., Skar, B., Tivoli, A. M., Zangrando, A. F. J. (eds.), Marine Ventures. Archaeological perspectives on human-sea relations. Sheffield/Bristol: Equinox, pp. 225239.

Sigvallius, B., 1994, Funeral Pyres. Iron Age cremations in North Spånga. Stockholm: Stockholm University.

Sørensen, S. A., 2016. Loose human bones from the Danish Mesolithic, in Grünberg et al., 2016: 63-72.

Srejović, D., Letica, Z., 1978. Vlasac. A Mesolithic settlement in the Iron Gates. Serbian Academy of Sciences and Arts, Monographs DXII. Beograd: Department of Historical Sciences.

Struwe, R., 2016. Ethnological records of Australia's sub-recent indigenes - their treatment of corpses before final deposition, in Grünberg et al., 2016: 885-901. 
Sulgostowska, Z., 2016. New data concerning Mesolithic burials in Polish territory, in Grünberg et al., 2016: 439-455.

Tørhaug, V., 2003. Torpum 9b - En boplass fra Nøstvetfasen med kulturlag og ildsteder. In

Glørstad, H. (Ed.), Svinesundsprosjektet Bind 2. Utgravninger avsluttet i 2002. Varia 55.

Oslo: Universitetets Kulturhistoriske Museer, 79-142.

Tõrv, M., 2016. Persistent Practices. A Multi-Disciplinary Study of Hunter-Gatherer Mortuary Remains from c. 6500-2600 cal BC, Estonia. Dissertationes Archaeologiae Universitatis Tartuensis 5. Tartu: University of Tartu Press.

Utne, A., 1971, Storbåthallaren i Flakstad, Vest-Lofoten, Nicolay 9, 14-16.

Zagorska, I., 2006. Radiocarbon chronology of the Zvejnieki burials. In Larsson, L., Zagorska, I. (Eds.). Back to the origin. New research in the Mesolithic-Neolithic Zvejnieki cemetery environment, northern Latvia. Lund: Almqvist \& Wiksell International, pp. 91-113. 
Supplementary material 1:

The Brunstad grave. Plan of the blocks that were extracted in the field for later excavation in the laboratory.

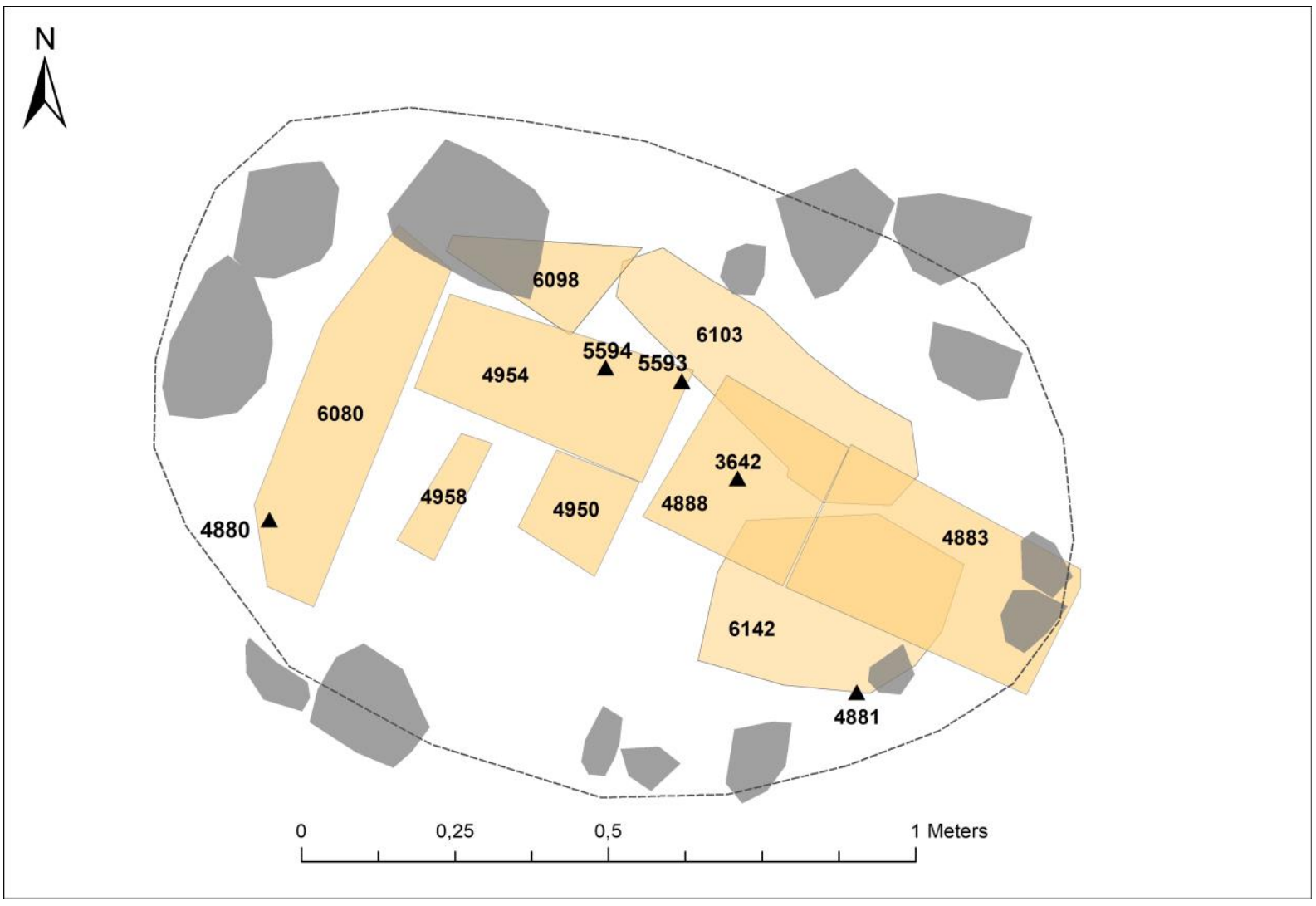




\section{Supplementary material 2:}

The Brunstad grave. List of the preserved bone elements. For the number and position of the blocks see Supplementary material 1.

\begin{tabular}{|c|c|c|c|c|c|c|c|}
\hline NISP & Species & Element & $\begin{array}{l}\text { Part of } \\
\text { Element }\end{array}$ & Side & Age & $\begin{array}{l}\text { Block (excavation } \\
\text { unit) }\end{array}$ & Comments \\
\hline 20 & Homo sap. & Cranium & Neurocrania & & Adult & 4950 & c. 20 fragments, 1 with part of suture. \\
\hline 3 & Homo sap. & Cranium & Neurocrania & & Adult & 3642 & \\
\hline 1 & Homo sap. & Cranium & Neurocrania & & & 4950 & \\
\hline 1 & Homo sap. & Cranium & Neurocrania & & Adult & 4950 & \\
\hline 1 & Homo sap. & Cranium & Neurocrania & & Adult & 4950 & \\
\hline 1 & Homo sap. & Cranium & Neurocrania & & Adult & 4888 & \\
\hline 1 & Homo sap. & Cranium & Neurocrania & & & 4888 & \\
\hline 1 & Homo sap. & Cranium & Neurocrania & & & 4888 & \\
\hline 2 & Homo sap. & Cranium & Neurocrania & & & 4888 & \\
\hline 1 & Homo sap. & Mandibula & Corpus & $\operatorname{Sin}$ & & 4950 & \\
\hline 3 & Homo sap. & Costae & 25 (corpus) & $D x t$ & & $5593 / 5594$ & \\
\hline 1 & Homo sap. & Radius & 75 & $D x t$ & & $6103+6098$ & $\begin{array}{l}\text { Complete diaphysis, no preserved } \\
\text { epiphysis }\end{array}$ \\
\hline 1 & Homo sap. & Ulna & 75 & $D x t$ & & $6103+6098$ & $\begin{array}{l}\text { Complete diaphysis, no preserved } \\
\text { epiphysis }\end{array}$ \\
\hline 2 & Homo sap. & Femur & 75 & $\sin$ & & 6080 & $\begin{array}{l}\text { Complete diaphysis, no preserved } \\
\text { epiphysis }\end{array}$ \\
\hline 1 & Homo sap. & Femur & 75 & $D x t$ & & 6080 & $\begin{array}{l}\text { Complete diaphysis, no preserved } \\
\text { epiphysis }\end{array}$ \\
\hline 4 & Homo sap. & Tibia & 50 & $\sin$ & & 6080 & $\begin{array}{l}\text { c. } 50 \% \text { of diaphysis, no preserved } \\
\text { epiphysis }\end{array}$ \\
\hline 1 & Homo sap. & Tibia & 50 & $D x t$ & & 6080 & $\begin{array}{l}\text { c. } 50 \% \text { of diaphysis, no preserved } \\
\text { epiphysis }\end{array}$ \\
\hline 1 & Homo sap. & Fibula & 50 & $\sin$ & & 6080 & $\begin{array}{l}\text { c. } 50 \% \text { of diaphysis, no preserved } \\
\text { epiphysis }\end{array}$ \\
\hline 6 & Homo sap. & Fibula & 75 & $D x t$ & & 6080 & $\begin{array}{l}\text { Complete diaphysis, no preserved } \\
\text { epiphysis }\end{array}$ \\
\hline 1 & Mammal & Unindent. & Fragment & & & 4881 & \\
\hline 4 & Mammal & Unindent. & Fragment & & & 4883 & \\
\hline 4 & Mammal & Unindent. & Fragment & & & 4883 & \\
\hline 1 & $\begin{array}{l}\text { Large } \\
\text { Mammal }\end{array}$ & Ossa longa & Fragment & & & 4880 & \\
\hline
\end{tabular}

